Volume and Issues Obtainable at Center for Sustainability Research and Consultancy
Journal of Business and Social Review in Emerging Economies
ISSN: 2519-089X (E): 2519-0326
Volume 6: Issue 2 June 2020
JSR
Journal homepage: www.publishing.globalcsrc.org/jbsee

\title{
Corporate Social Responsibility and its Nexus with Firm Performance and Institutional Ownership: An Emerging Market Context
}

\author{
${ }^{1}$ Amna Noor, ${ }^{2}$ Muhammad Farooq, ${ }^{3}$ Mahwish Yamin, ${ }^{4}$ Saleh Nawaz Khan \\ ${ }^{1}$ Assistant Professor, School of Business Management and Administrative Sciences, The Islamia University of \\ Bahawalpur, Bahawalpur-Pakistan, damnanoorch@gmail.com \\ ${ }^{2} \mathrm{PhD}$ student in Finance, School of Business Management and Administrative Sciences, The Islamia University of \\ Bahawalpur, Bahawalpur-Pakistan, alihussnain155@yahoo.com \\ ${ }^{3} \mathrm{PhD}$ student in Finance, School of Business Management and Administrative Sciences, The Islamia University of \\ Bahawalpur, Bahawalpur-Pakistan, mahwish yamin@ hotmail.com \\ PhD student in Finance, School of Business Management and Administrative Sciences, The Islamia University of \\ Bahawalpur, Bahawalpur-Pakistan, sallehkhan@yahoo.com
}

\begin{tabular}{l}
\hline ARTICLE DETAILS \\
\hline History \\
Revised format: May 2020 \\
Available Online: June 2020 \\
\\
\hline Keywords \\
Corporate social responsibility, \\
firm performance, Pakistan \\
stock exchange, Institutional \\
ownership
\end{tabular}

JEL Classification

MO, M1

\begin{abstract}
Either corporate social responsibility (CSR) is paramount for the firms or not, is a matter of question since long. The present study analyzes this relationship in the context of moderating role of Institutional ownership (IO). Firm performance is measured through accounting and market value measures. Leverage, firm age, firm size, and log of sales revenue used as a control variables. Through applying panel data techniques, findings demonstrate insignificant positive association between CSR and firm performance. It shows that stakeholder could not assign value to firms spending as a CSR. This could be the reason that customers are not much aware about firms CSR activities hence, firms fail to capitalize their spending as an investment. Institutional Ownership (IO) reveals negative insignificant association with all profitability measures except Tobin's Q where this relationship is significant. This significant negative relationship supports the agency theory and presence of strategic alliance hypotheses between influential institutional owners and internal management that leads to lower firm performance. The interaction variable of CSR and IO show positive but insignificant relationship with firm performance by all means.
\end{abstract}

\section{OPEN ACCESS}

(C) 2020 The authors, under a Creative Commons AttributionNonCommercial 4.0

Corresponding author's email address: sallehkhan@yahoo.com

Recommended citation: Noor, A., Farooq, M., Yamin, M. and Khan, S. N. (2020). Corporate Social Responsibility and its Nexus with Firm Performance and Institutional Ownership: An Emerging Market Context. Journal of Business and Social Review in Emerging Economies, 6(2), 845-858

\section{Introduction}

Traditionally, corporations are established as profit-generating entities following the free market philosophy. The 
primary focus of these entities is on maximizing their shareholders' wealth without considering a social perspective or the broader implications of the way they run the business (Jamali et al., 2008). As bigger corporations emerged in the wake of the Second Industrial Revolution1, they tended to have greater power and control over various global resources, and became increasingly subject to a regulatory framework of welfare legislation. This realized huge changes in the practices and structure of modern business and society (Jensen, 1993). These changes constituted a new social paradigm, which shifted the focus of organizations from merely achieving their economic goals towards understanding and espousing social goals as well in their business strategy. Moreover, the start of various social movements in the 1960s and 1970s such as the demand for civil rights, women's rights, labor rights and environmentalism and consumerism further broadened the concept of the organizations' responsibility towards their society and workers (Carroll \& Shabana, 2010; Visser, 2010). These movements made organizations realize that as change agents in a variety of organizational practices, they wielded greater power to shape various organizational, social and economic behaviors in society as a whole. They therefore needed to be more responsive towards social demands. In realizing their role as major change agents in the social and economic field, they also sought to be more responsive and responsible to their society and its demands (Hussain \& Moriarty, 2016). As a result of these developments, the concept of corporate social responsibility (CSR) emerged as a standout amongst the most key concerns for management, and has become the subject of an academic discussion throughout the last few decades (Jo \& Harjoto, 2011; Karaosmanoglu et al., 2016).

Finance theories witnesses that the only objective of the organization is to maximize the shareholder's wealth (Arnold and Valentin, 2013). This objective explains that to satisfy the shareholders is the prime objective of the organization but nowadays this is not the case as firms are not only affected by stockholders but the other stakeholders as well (Singh, 2014). Stakeholders not only emphasis on financial performance (FP) but non-financial interests as well like social welfare, improvement in community and the environment (Pirsch et al., 2006). A UN Global-Accenture CEO study in 2010 shows that 93 percent of 766 CEOs who take participate in this study considered CSR as "important" or "very important" for the continuity of the business for the longer period of time (UN, 2010). Firm's response and behavior towards the relationship with society is depicts the sustainability of the firm in society. Sprinkle and Maines (2010) remarks that in the past firms emphasis only on sales growth, but this is not the case in now a days as firms have to focus on their other stakeholders as well to continue the business for a longer period of time. Stuebs and Sun (2015) narrates that this relationship is based on trust and this trust is developed by attending and exceeding responsibilities to society.

Despite plenty of work on CSR by researchers (Browen, 1953; Donham, 1972), the CSR concept remained in deprivation from any unified supporting theory. There are two alternative explanations available in literature regarding the existence of CSR. First, based on agency theory, Barnea and Rubin (2010) claimed principal-agent relationship is the reason of mere existence of CSR engagements of firm and that managers are interested in overinvestment in CSR to gain private benefits by way of rising reputation as a formal civilian, at the expense of shareholders. This will extend their career opportunities and better negotiation power in the employee market. This overconfidence of managers sometimes makes value destroying investment. Bertrand and Mullainathan (2003) claimed that without active monitoring of managers, building an active empire of business is not possible. Second to appease all stakeholders are not possible.

There is a stakeholder theory that focuses on conflict resolution among stakeholders (e.g. Jensen, 2002; Scherer et al., 2006) by arguing that managers use effective monitoring / governance mechanisms along with CSR to resolve conflict among stakeholders. This spending will help firms to gain support and confidence of stakeholders by the way of creating reputation, customer satisfaction, and competitive advantage in the market (Walsh \& Beatly, 2007; Salmons et al., 2009).

The emphasis on CSR and its disclosure increases by virtue of different corporate disasters regarding the community, environment, and human resources (Waller \& Lenis, 2009). Now firms feel pressure from the customers end as well to focus on CSR to remain in the market. To build trust-worthy relationship and social capital is an important outcome of CSR and this social capital analyzed by different researchers in different dimensions like in connection with economic growth (Knack and Keefer, 1997), trust building (La porta et al., 1997a), financial development (Guiso et al., 2004). 
"Is the investment in CSR increases firm's profitability" an unresolved question that has been attended by researchers for a long time. Fisman et al., (2005) studied CSR in connection with the accounting profit and concluded that in competitive industries, this relation worked more productively and efficiently. Goss and Roberts (2007) studied the phenomena in the context of bank loans and concluded that firms having worse CSR rating pay a higher cost of the loan than high rating CSR firms. Conversely, Barnea and Rubin (2010) argue that CSR activities are not value enhancing for the firms, they merely destroy valuable resources of the firm. The discussion on CSR-value relationship continues since long without a consensus on its direction regarding firm's value.

"How does CSR jointly with institutional ownership (IO) effects firm value" is the second question that present study intended to resolve. In this paper, through applying panel data techniques, we document that IO positively moderate the CSR-firm value relationship. In firms, the discretionary power to make spending in CSR activities remains in the hands of management. It has a significant impact on firm performance as suggested by over-investment hypothesis and conflict resolution hypothesis. Ownership structure is a productive governance mechanism to check this over-investment and conflict resolution behavior of the manager, as it depicts who has the ultimate decision-making power in an organization (Zattoni, 2011). IO is one of the major components of ownership structure of any firm. Institutional shareholders are to be considered an active monitoring device as per agency theory and institutional support theory. Active monitoring hypotheses posit that institutions have the right combination of resources, capabilities to actively monitor the firm and hence effective check on management and avert them from self-serving behavior (Sheifer \& Vishny, 1986; McConnell \& Servaes, 1990). So influential institutional investors help to counter this overinvestment in CSR through enhanced monitoring (Chen et al., 2007; Starks, 2009; Gillan et atl., 2010). On the other hand (Lemmon and Lins, 2003; Guiso et al., 2015) claims that it can raise the conflict between shareholders and non-investing stakeholders, which overturn the CSR conflict-resolution hypothesis.

This paper fulfills three objectives. First, it examines the CSR-firm performance relationship on a sample of 215 Pakistan Stock Exchange (PSX) listed firms for the period 2010-2017. Secondly, we strengthen the CSR literature by showing that CSR value effect varies with institutional investment level. Lastly, present study provides valuable policy implications and recommendations for companies, regulators, academics, and other shareholders in the context of CSRIO value relationship.

The remainder of the paper is arranged as follows. Section 2 covers CSR practices in Pakistan; Theoretical approaches to CSR and financial performance explains in Section 3; Section 4 illustrate literature review on IO, CSR, and firm financial performance; Methodology covers in Section 5; Section 6 presents results and discussion, conclusion and future research perspective covers in Section 7.

\section{CSR in Pakistan}

CSR is mainly associated with the western world. These economies have predefined rules and regulations, mature capital markets, adoption of corporate governance (CG) mechanism, protection of shareholder's rights which lacks in developing Asian economies (Chapple \& Moon, 2005). Poor legislation, dominance of concentrated ownership, weak CG system is the main hindrance in adoption of CSR in Pakistan. Since in the last few years, CSR remained a widely discussed topic at different platforms but still looking much effort towards adoption of CSR in the practical world. In the corporate world, there are a few organizations like Pakistan State Oil, Shell, Unilever, and ICI- that act responsibly and disburse their earnings in society by way of CSR (Mian, 2010; Yunis et al., 2018).

Responsibilities lie at both ends regarding the present scenario of CSR in Pakistan. At one end, the public is not fully aware of their rights and responsibilities because of lack of education and awareness. Second, due to deficiency in predefined rules and regulation about CSR, corporations too not give priority in their strategic decisions. The Securities and Exchange Commission of Pakistan (SECP) took the ownership and issued guidelines about companies regarding disclosure of information about 'donations' in their financial statements in compliance with the Companies Ordinance 1984, part III, E-1 of Schedule 4. It further introduces Workers Welfare Fund Ordinance (WWF) 1971, which makes compulsion to firms to do participate in workers welfare schemes and presents the same in annual reports. Furthermore, there are different legislations made by regulatory authorities to promote CSR practices in Pakistan like inauguration of IAS 19 by ICAP, Pakistan Environment Protection Act by National Environment Quality Standard board, launching of ACCA-WWF Pakistan Environment Reporting Awards by Ministry of Environment, SECP's general order 2009 which 
is about disclosure of CSR activities by firms. Further, in 2013 SECP issued CSR Voluntary Guidelines to enhance accountability of the organizations. Now CSR is growing in the corporate world by accumulating efforts of government, regulatory bodies, companies and academic researchers. However, still there is a long journey to establish a CSR framework in organizations.

\section{The Theoretical Approaches of CSR and Firm Performance}

Predominantly, CSR-firm performance relationship can be well explained with the help of four theoretical approaches, namely, trade-off hypothesis, the supply and demand theory of the company, the social impact hypothesis, and the theory of modern corporate stakeholders (Salzmann et al., 2005; Laan et al., 2008).

The trade-off hypothesis presented by Friedman (1970) claims that firm's only social responsibility to enhance firm FP. Hence, the involvement in CSR activities brings additional expenses, which in turn decreases firm's profitability. (Salzmann et al., 2005). So this theory places a company in a disadvantageous position who involved in CSR activities as compare to opponent firms. In this context, CSR has an inverse relationship with firm's FP (Moore, 2001; Vance, 1975).

Supply and demand theory of the company presented by McWilliams and Siegel (2001), which narrates that demand for the involvement of a company in CSR activities maximize company's profits. Stegar et al., (2007) noted that in an equilibrium condition, the level of CSR may vary; however, profit may be maximized or not changed. Hence, there is no relationship between CSR and firm's FP. Earlier empirical studies like Mahoney and Roberts (2007); Patten (1990); Freedman and Jaggi (1988) support this theory and fails to link any association between CSR and FP.

The social impact hypothesis presented by Cornell and Shapiro (1987) demonstrate that firm investment in CSR activities enhances firm's FP. Thus the investment in CSR activities always in return provides greater reward to the firm (Steger et al., 2007). This positive relationship could be attributed as investment made in CSR could increase firm's reputation, build strong binding with stakeholders and minimizes the risk of the company. The earlier studies of Simpson and Lohers (2002); Waddock and Graves (1997); Roberts (1992) has found a positive impact of CSR on FP of respective firms.

The stakeholder theory too constructs the relationship between CSR and FP (Barnett, 2007; Jones, 1995) through keeping emphasis on stakeholders. Some stakeholders have explicit claims on company's resources like shareholders, employees and the government while some have implicit claims e.g. the continuity of supplies, on-time delivery, work safety, gradually increase in the quality of a company's product etc as demanded by the customers, suppliers, and employees etc. The price that must be paid by stakeholders for this claim depends on the company's situation, including the financial policy applicable to the company.

This section provides the theoretical linkages between CSR and firm performance. The theories presented in this section concur that there exist a mere relationship between CSR and FP. Like, trade-off theory witnesses the prevalence of CSR-firm value association but it is an indirect relationship. In addition, stakeholder theory is widely accepted in literature is more relevant to theorize the relationship between CSR and FP.

\section{Literature Review}

\subsection{CSR and Firm Value}

Corporate social responsibility concept has been in academic debate since 1970s. Different authors have explored CSR in different dimensions. One of the oldest definition of CSR explained by Friedman (1970) as CSR is all about to conduct business as per shareholders desire, to make as much money but confronting the basic rules of society both expressed in law and those embodied in ethical custom. In economic development history, CSR is to be considered as a key ingredient to accomplish economic goals and wealth generations. Therefore, a number of studies tried to bridge a link between CSR and FP (Galbreath \& Shum, 2012; Lin et al., 2009).

Overinvestment hypothesis recommends negative relationship between CSR and FP (Cespa and Cestone, 2007; Barnea and Rubin, 2010). In organizations, there is an agency issue because resources are not in the hands of real investors but rather these are trusted to corporate managers who are suppose to work for the best interest of these resource providers 
i.e. shareholders. Based on this agency issue, managers are interested to goes beyond the rational limit of CSR investment to build its reputation and enhance its image as a socially responsible manager at the cost of stockholders. In other words, it is to be considered as diversion of valuation organization's resources due to conflict of interest between managers and shareholders. Barnea and Rubin (2010) noted that managers have an incentive to move beyond the optimum level in term of expenditure in CSR. As such, this overinvestment in CSR can destroy firm value. They also found that higher insider's shareholdings negatively associate with CSR activity. In the same way, Kruger (2015) found that there is substantial cost attached to social irresponsible behavior.

Contrarily, conflict resolution hypothesis predicts that CSR investment enhances FP (Freeman, 1984; Makni et al., 2009; Jo and Harjoto, 2011, 2012). According to this hypothesis, manager uses CSR as a weapon to minimize this unrest situation between shareholders and non-equity holders. Further, Jo and Harjoto $(2011,2012)$ argues that CSR activities are the better mechanism to communicate between insiders and outsiders, thus in this way mitigate the conflict of interest between the two and raised firm value. Guenster et al., (2010) and jiao (2010) found that corporate social performance is positively associated with firm value. Cui et al., (2018) narrates that CSR activities help to minimize the information asymmetry issue between manager and non-investing stakeholders which in turn reduce the conflict of interest between them; hence raise firm value.

Although, majority of existing studies suggested a positive association between CSR and FP. But literature also witnesses a number of studies that document otherwise. Brammer et al., (2006) suggest higher social performance leads to lower shareholder's value. Nelling and Webb (2009) found no association between CSR and firm's financial performance. Crisostomo et al., (2011) studies the non-financial Brazilian firms and found inverse relationship between CSR and Tobin's Q.

\subsection{Institutional Shareholdings, CSR, and Firm Value}

Institutional ownership (IO) can impact on CSR-firm value relationship in two different ways. On the one hand, IO can positively interest with CSR-firm value association by minimizing the agency cost and overinvestment behavior of the manager through effective monitoring and efficient allocation of firm's resources. IO is to be considered an active monitoring device that advocates the agency theory and institutional support theory. Researchers like (Shleifer \& Vishny, 1986; McConnell \& Servaes, 1990; Pound, 1988) support the active monitoring hypothesis by claiming that institutions have right combinations of resources, expertise, and capability to monitor firm's management and prevent them from opting self-serving behavior. Mitra (2002) claims that IO is an effective mechanism to counter principalagency information asymmetry hence, increase the value of the firm. Significant relationship observed between IO and firm performance by the number of researchers like Al-Malkawi and Pillai (2018), Lee and Chen (2011), Gugler et al., 2008. According to active monitoring hypotheses, it is expected that IO significantly supports CSR positively (conflict resolution hypothesis) rather than negatively (overinvestment hypothesis). Literature witnesses that presence of blockholders or institutional investors helps to mitigate overinvestment CSR by way of effective monitoring (Chen et al., 2007; Starks, 2009; Gillan et al., 2003). Contrarily, the presence of Institutional investors can exacerbate the conflict between equity holders and non-equity holders stakeholders (Lemmon and Lins, 2003; Guiso et al., 2015), which resultantly overshadows the CSR conflict-resolution hypothesis. Thus, effective monitoring mechanism of an institutional investor can shield shareholders against value-destroying activities related to CSR engagement.

On the other hand, IO can suppress this positive CSR-firm value relationship by raising the unrest situation between shareholders and non-equity stakeholders. Further, institutional investor can negatively impact on information disclosure, thereby raising information asymmetry between shareholders and non-equity stakeholders. High institutional shareholdings decrease management incentives and integrity (Burkart et al., 1997; Guiso et al., 2015), which in turn reduces firm's productivity and firm value (Tobin's Q). Moreover, institutional shareholders can extract own private benefits and not shared the same with minority shareholders and CSR-related stakeholders (Edmans, 2014).

Recently, a very similar study made by Buchanan et al., (2018) in the context of U.S. in which they studied CSR-firm value relationship in the context of influential IO. They conclude that CSR-firm value association depends upon influential IO and economic conditions. By employing difference-in-difference method, they found that CSR oriented firm enjoys higher profit than the opponent before the 2008 crises but after these results are quite opposite that CSR 
oriented firm experience more losses than the counterpart. So the direction of CSR-firm value association depends upon the dominance of either conflict-resolution hypotheses or overinvestment hypothesis.

\section{Methodology}

\subsection{Data Collection and Sample Selection}

The present study aims to investigate the CSR-FP relationship with a moderating effect of IO on non-financial PSX listed firms for the year 2010 to 2017. The selection of non-financial sector is based upon two reasons i.e. it is the third largest sectors of the economy that contribute 13.5 per cent of gross domestic product (GDP) and provide $14 \%$ of the total employment. Second, financial firms skipped from the initial sample because of different tax and accounting rules and regulations. Moreover, financial firms are under strict scrutiny by the state-owned enterprises and restructuring of financial sector since 1990 resulted inconsistency and wobbly financial sector data (Shahab et al., 2018). As a result 126 financial firms skipped from the initial sample. This brings down the sample to 473 non-financial firms. In addition 205 non-financial firms skipped from sample due to non-availability of financial reports as well as merger, discontinuity in operation, and continued operating losses. Our final sample consists of 268 non-financial firms, representing $45 \%$ of total population of PSX listed firms during the study period. This study uses secondary data that gathered from different sources like annual reports of respective firms, SBP financial statement analysis data, brecorder.com, and from SECP website for the period from 2010 to 2017 . The collected data organized in a panel for analysis. According to Baltagi et al., (2005), panel data is suitable for data analysis as it provides both time-series and cross section dimensions.

After collecting the data of relevant variables, the initial data screening process depicts the presence of outliers which could create a disturbance in the generalization of the empirical results. To overcome this problem, we winsorized all continuous variable at $1 \%$ as this technique is helpful in order to control the influence of extreme values and outliers (Shahab et al., 2018).

\subsection{Measurement of Variables and Data Analysis}

The measurement and operationalization of studied variables shown in table below

Table 1. Description of Variables Used in Study

\begin{tabular}{|c|c|c|}
\hline Variable & Measurements & Notation \\
\hline \multicolumn{3}{|l|}{ Dependent Variables } \\
\hline Return on Assets & Ratio of Net income to total assets & $\mathrm{ROA}$ \\
\hline Return on Equity & Ratio of Net income to average shareholder's equity & ROE \\
\hline Tobin's Q & Market value of equity/Book value of assets & Tobin's Q \\
\hline Net profit margin & Ratio of Net income to sales & NPM \\
\hline Return on sales & Ratio of EBIT to sales & ROS \\
\hline Earning Yield & Ratio of EPS/MV per share & EY \\
\hline \multicolumn{3}{|l|}{ Independent Variables } \\
\hline Investment in CSR & Expenditures made in Donations, Charity etc & ICSR \\
\hline Institutional Ownership & Fraction of shares held by Institutions & IO \\
\hline \multicolumn{3}{|l|}{ Control Variables } \\
\hline Firm size & Log of Total assets & Fsize \\
\hline Firm Age & Present year-Incorporation year & Fage \\
\hline Leverage & Debt/Total Assets & Lev \\
\hline Log of Sales Revenue & Log of Annual sales & LSR \\
\hline
\end{tabular}

2.

The relevant variable data collected and arranged in a panel for analysis. To summarize and pattern of data, descriptive statistics used such as measures of central tendency, measures of dispersion. Further, STATA version 11used for regression analysis. 


\subsection{Empirical Model Specification}

In this study, we investigate the impact of CSR on FP and secondly we evaluate the impact of IO on CSR-FP relationship. To furnish these objectives, we used two regression models i.e. equation 1 diagnoses the primary affect of CSR on FP while equation 2 shows the moderating effect of IO between CSR and FP relationship. Owning to data is panel in nature, panel fixed effects or panel random effects are the modeling techniques that used to observe the findings. The Hausman tests are conducted; the results support the use of the fixed-effects models as p-value $<0.00$ in all performance measures.

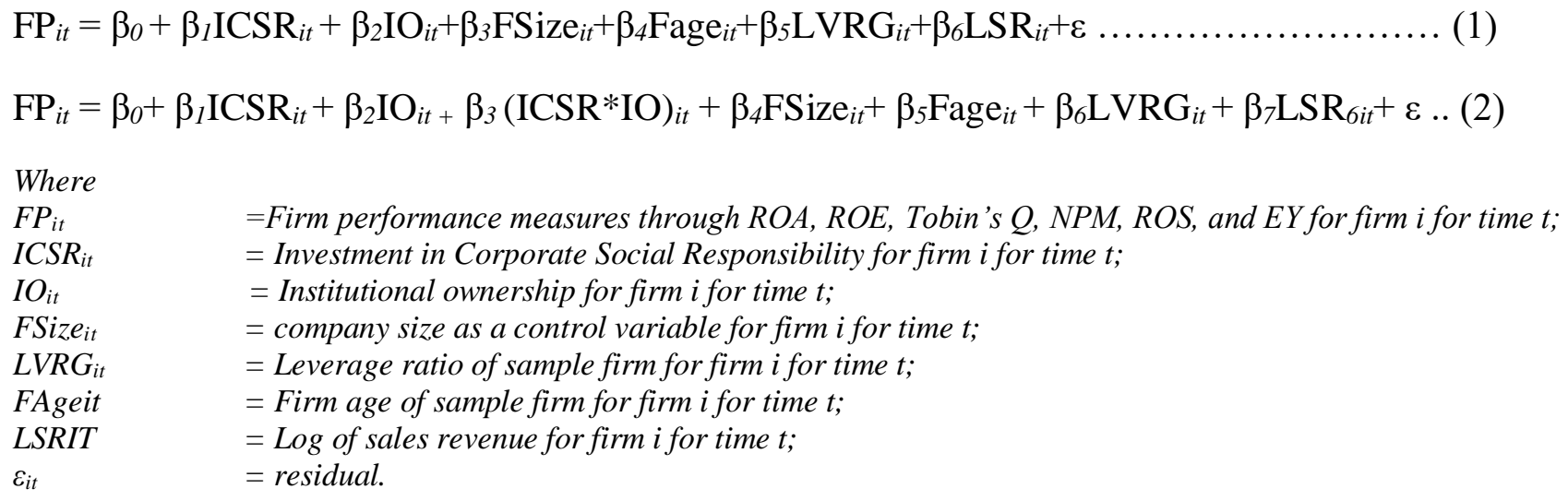

\section{Results and Discussion}

\subsection{Descriptive Statistics and Correlation Analysis}

Table 2 presents the descriptive statistics of studied variables. Investment in CSR is measured through the expenditures made by the organization in donations and charity etc.

Table 2: Descriptive Statistics of Variables

\begin{tabular}{|c|c|c|c|c|c|}
\hline Variable & Obs & Mean & Std. Dev & Min & Max \\
\hline $\mathrm{ROA}$ & 2136 & 0.059 & 0.1122 & -0.2336 & 0.4353 \\
\hline ROE & 2136 & 0.138 & 0.375 & -1.366 & 1.901 \\
\hline Tobin's Q & 2136 & 0.785 & 1.245 & 0.018 & 7.762 \\
\hline NPM & 2136 & 0.015 & 0.368 & -2.713 & 0.960 \\
\hline ROS & 2136 & 0.078 & 0.291 & -1.64 & 1.100 \\
\hline EY & 2136 & -0.039 & 0.823 & -4.322 & 2.165 \\
\hline ICSR & 2136 & 7.247 & 21.827 & 0 & 154.081 \\
\hline IO & 2136 & 11.714 & 11.319 & 0 & 53.000 \\
\hline $\begin{array}{l}\text { Fsize (Million PK } \\
\text { Rupees) }\end{array}$ & 2136 & 19542.88 & 41691 & 22.195 & 395943.000 \\
\hline LVRG & 2136 & 0.274 & 0.228 & 0 & 0.997 \\
\hline F Age & 2136 & 35.625 & 17.654 & 6 & 102 \\
\hline LSR & 2136 & 9.556 & 0.802 & 6.888 & 11.245 \\
\hline
\end{tabular}

Note: This table reports the descriptive statistics of return on assets (ROA), return on equity (ROE), Tobin's Q, net profit margin (NPM), return on sales (ROS), earnings yield (EY), investment in corporate social responsibility (ICSR), institutional ownership (IO), firm size (Fsize), leverage (LVRG), firm age (Fage), and log of sales revenue (LSR). Sample period is from 2010-2017 and composed on 268 non-financial PSX listed firms.

Result shows that, on average the ROA of sample data is $5.96 \%$ with a minimum and maximum value of $-23.36 \%$ and $43.53 \%$ respectively. Mean value of ROE is $13.76 \%$ with a standard deviation of 0.375 . The range of ROE is from $136.65 \%$ to $190.06 \%$. Tobin's Q ranges from 0.018 to 7.762 with a mean value of 0.785 . The average net profit margins of sample firms are $1.45 \%$ with a standard deviation of 0.368 and a minimum and maximum value of $-271.3 \%$ and 96 $\%$ respectively. Sample firms have on average $7.79 \%$ of Return on sales with a range from $-164 \% \%$ to $110 \%$ of sales. The average earning yield of data is $-3.91 \%$ with a minimum value is $-432.2 \%$ and maximum value is $216.50 \%$. On average contributions in CSR of sample firms are 8.378 million with a minimum of 0 and maximum value of Rs. 586.293 million. The range of IO is from 0 to $53 \%$ with a mean value (standard deviation) is 11.714 (11.320). The mean value of IO is quite close to standard deviation which show there is not much deviation regarding IO in sample data. 
The average firm size 19542.88 million PKR with a minimum and maximum total assets are 22.195 million PKR and 395943 million PKR respectively. On average, firms have $27.35 \%$ leverage with standard deviation of 0.228 . The minimum and maximum leverage among sample firms is $0 \%$ a $\mathrm{d} 99.7 \%$ of total assets respectively. Firm's age on average is 35 years with a maximum age of sample firms are 102 years.

Table 3. Correlation Matrix Results

\begin{tabular}{|c|c|c|c|c|c|c|c|}
\hline Variable & ICSR & IO & ICSR* IO & FS & F Age & Lev & LSR \\
\hline ICSR & 1 & & & & & & \\
\hline IO & -0.0155 & 1 & & & & & \\
\hline ICSR $*$ IO & $0.535^{* * *}$ & $0.203^{* * *}$ & 1 & & & & \\
\hline Fsize & $0.337 * * *$ & $0.0573^{*}$ & $0.276^{* * *}$ & 1 & & & \\
\hline Fage & $-0.0814 * * *$ & -0.0246 & -0.0270 & 0.00710 & 1 & & \\
\hline LVRG & -0.00974 & 0.0449 & -0.0328 & 0.0380 & $-0.189 * * *$ & 1 & \\
\hline LSR & $0.262 * * *$ & $0.0543 *$ & $0.228 * * *$ & $0.488 * * *$ & 0.0470 & -0.0456 & 1 \\
\hline
\end{tabular}

Note: The correlation matrix is presented for investment in corporate social responsibility (ICSR), institutional ownership (IO), firm size (Fsize), leverage (LVRG), firm age (Fage), and log of sales revenue (LSR) for the year 2010 - 2017.

Table 3 presents the correlation between independent and controlled variables. Following Andersen et al., (1990), any correlation coefficient value above 0.7 witnessed presence of multicollinearity among explanatory values. As result shows, there is not any value above 0.7 , so there is no multicollinearity issue present in our model.

\subsection{Panel Model Regression Results}

To select which panel effects (fixed effect and random effect) model is appropriate for the analysis, a Hausman test is conducted with a null hypothesis that a random effect model is appropriate. The results of the Hausman test with all profitability measures are less than significance level i.e. 0.05. Hence fails to accept the null hypothesis that the random effect model is appropriate, rather fixed effect model is appropriate to observe the relationship between CSR and firm value.

Table 4 shows the panel regression results with CSR and IO used as an independent variable and firm profitability measures i.e. ROA, ROE, Tobin's Q, NPM, ROS, and EY used as a dependent variable along with firm size, firm age, leverage, sales revenue as control variables. As per Hausman test results, fixed effect model panel data analysis conducted to empirically examine the impact of CSR and IO on firm's profitability. Results reveal that investment in CSR has significant positive impact on profitability in term of ROA and Tobin's Q while it remains insignificant with other profitability measures.

Table 4: Fixed Effect Panel Regression Results (for primary effect)

\begin{tabular}{lcccccc}
\hline & ROA & ROE & Tobin's Q & NPM & ROS & EY \\
& $($ FEM) & $($ FEM) & $($ EEM) & $($ FEM) & $($ FEM) & $($ FEM) \\
\hline ICSR & $0.0004^{* * *}$ & 0.0004 & $0.0038^{* *}$ & 0.0005 & 0.0007 & 0.0001 \\
& $(2.69)$ & $(0.66)$ & $(2.38)$ & $(0.88)$ & $(0.17)$ & $(0.13)$ \\
IO & 0.0007 & -0.0001 & $-0.0067^{*}$ & -0.0012 & 0.0003 & -0.0021 \\
& $(0.01)$ & $(-0.04)$ & $(-1.77)$ & $(-0.96)$ & $(0.02)$ & $(-0.66)$ \\
Fsize & -0.0196 & $0.1067^{* *}$ & $-0.0060^{* *}$ & -0.0280 & 0.0093 & $-0.3825^{* * * *}$ \\
& $(-1.58)$ & $(2.04)$ & $(0.005)$ & $(-0.63)$ & $(0.26)$ & $(-3.67)$ \\
LVRG & $-0.1842^{* * *}$ & $-0.4278^{* * *}$ & $-0.9946^{* * *}$ & $-0.2523^{* * *}$ & $-0.1689^{* * *}$ & $-0.4782^{* * *}$ \\
& $(-11.59)$ & $(-6.23)$ & $(-5.90)$ & $(-4.39)$ & $(-3.64)$ & $(-3.54)$ \\
Fage & $-0.0070^{* * *}$ & $-0.0303^{* * *}$ & $0.1125^{* * *}$ & $-0.0120^{* * *}$ & $-0.0045^{*}$ & $-0.0069^{* * *}$ \\
& $(-7.70)$ & $(-7.76)$ & $(0.000)$ & $(-3.66)$ & $(-1.72)$ & $(-0.91)$ \\
LSR & $0.0695^{* * *}$ & $0.1917^{* * *}$ & $0.1933^{* *}$ & $0.2554^{* * *}$ & -0.0154 & $0.3116^{* * *}$
\end{tabular}




\begin{tabular}{lcccccc} 
_cons & $-0.1149^{* * *}$ & $-1.5269^{* * *}$ & $-4.8148^{* *}$ & $-1.6413^{* * *}$ & $0.3523^{* * *}$ & $1.0759^{*}$ \\
& $(-0.94)$ & $(-3.00)$ & $(-3.81)$ & $(-3.85)$ & $(1.02)$ & $(1.06)$ \\
\hline$N$ & 2136 & 2136 & 2136 & 2136 & 2136 & 2136 \\
adj. $R^{2}$ & 0.1564 & 0.0740 & 0.1811 & 0.0612 & 0.0113 & 0.0299
\end{tabular}

Note: We estimate fixed effect model as a panel data analysis technique for entire profitability measures as a dependent variables and investment in corporate social responsibility (ICSR) and institutional ownership (IO) used as an independent variables; while firm size (Fsize), leverage (LVRG), firm age (Fage), and log of sales revenue (LSR) used as a control variables. Sample period is from 2010-2017 and finally composed of 268 nonfinancial PSX listed firms.

The participation of CSR activities not only ensures higher accounting profit but also it enhances the reputation of the firm in the market which in turn may leads to higher Tobin's Q. This positive relationship between CSR and profitability support the earlier findings including Kanwal (2013), Nadeem and Malik (2014), Mahoney and Roberts (2007), Wu and Shen (2013), Kang et al., (2010). IO shows insignificant negative association with profitability but in relation with Tobin's Q, this relationship is significant. It shows that presence of IO in equity structure negatively perceived by the market participant as presence of IO can subdue the value enhancement of CSR by stimulating the conflict between shareholders and non-investing stakeholders. Hence assign lower market value. This negative association support the argument that presence of IO in PSX listed firms brings an agency issue between influential IO and minority shareholders and further it support the strategic alliance hypothesis which is presented by pound (1988), that IO make a strategic alliance with insiders which is harmful other shareholders. Jensen and Meckling (1976) too claims that in an organization shareholders having majority stake can expropriate the rights of minority shareholders which ultimately loss firm value. Moreover, Pound (1988) contended that IO build a strategic alliance with the management, which leads a negative relation between IO and firm value as suggested by Craswell (1997), Navissi and Naikder (2006), Afza and Salahudin (2007), and Alipour and Amjadi (2011).

Table 4 also presents the impact of control variables on profitability. Firm size shows significant positive association with entire measures of profitability. Large size firms have economies of scale and economies of scope benefits along with experience, technical expertise which in turn enhance firm's profitability. Increased debt ratio not only increased burden on firm's paying capacity but also a negative impression of firm into capital market which reduces market value. Firm's age has shown a significant negative relationship with the firm's profitability. Sales revenue shows a significant positive relationship with the firm's profitability.

Table 5: Regression Results (for Moderated effect of Institutional ownership)

\begin{tabular}{|c|c|c|c|c|c|c|}
\hline & $\begin{array}{c}\text { ROA } \\
\text { (FEM) }\end{array}$ & $\begin{array}{c}\text { ROE } \\
\text { (FEM) }\end{array}$ & $\begin{array}{c}\text { Tobin's Q } \\
\text { (FEM) }\end{array}$ & $\begin{array}{c}\text { NPM } \\
\text { (FEM) }\end{array}$ & $\begin{array}{c}\text { ROS } \\
\text { (FEM) }\end{array}$ & $\begin{array}{c}\text { EY } \\
(\text { FEM) }\end{array}$ \\
\hline \multirow[t]{2}{*}{ ICSR } & 0.0002 & 0.0001 & $0.0042 * *$ & 0.0002 & 0.0001 & 0.0000 \\
\hline & $(0.97)$ & $(0.17)$ & (1.96) & $(0.36)$ & $(0.19)$ & $(0.02)$ \\
\hline \multirow[t]{2}{*}{ IO } & -0.0001 & -0.0002 & $-0.0065^{*}$ & -0.0013 & 0.0000 & -0.0021 \\
\hline & $(-0.36)$ & $(-0.15)$ & $(-1.65)$ & $(-1.03)$ & $(0.09)$ & $(-0.66)$ \\
\hline ICSR* & 0.0001 & 0.0001 & 0.0001 & 0.0002 & 0.0084 & 0.0090 \\
\hline IO & (1.55) & $(0.49)$ & $(0.28)$ & $(0.45)$ & $(0.49)$ & $(0.12)$ \\
\hline \multirow[t]{2}{*}{ Fsize } & -0.0195 & $0.1069 * *$ & 0.0062 & -0.0280 & -0.0095 & $-0.3825 * * *$ \\
\hline & $(-1.58)$ & (2.04) & $(0.05)$ & $(-0.63)$ & $(0.27)$ & $(-3.67)$ \\
\hline \multirow[t]{2}{*}{ LVRG } & $-0.1844^{* * *}$ & $-0.4284^{* * *}$ & $-0.9961^{* * *}$ & $-0.2525^{* * *}$ & $-0.1692^{* * *}$ & $-0.4784^{* * *}$ \\
\hline & $(-11.60)$ & $(-6.23)$ & $(-5.90)$ & $(-4.39)$ & $(-3.65)$ & $(-3.54)$ \\
\hline \multirow[t]{2}{*}{ Fage } & $-0.0071^{* * *}$ & $-0.0305^{* * * *}$ & $0.1127^{* * * *}$ & $-0.0121^{* * *}$ & $-0.0047^{*}$ & -0.0070 \\
\hline & $(-7.78)$ & $(-7.78)$ & (11.69) & $(-3.68)$ & $(-1.75)$ & $(-0.91)$ \\
\hline \multirow[t]{2}{*}{ LSR } & $0.0694^{* * * *}$ & $0.1917^{* * * *}$ & $0.1935^{* *}$ & $0.2554 * * *$ & $0.0155^{\text {*** }}$ & $0.3116^{* * *}$ \\
\hline & (7.64) & $(5.01)$ & $(2.04)$ & (7.89) & $(0.59)$ & $(4.10)$ \\
\hline \multirow[t]{2}{*}{ _cons } & -0.1107 & $-1.5212 * * *$ & $-4.8246^{* *}$ & $-1.6372 * * *$ & -0.3796 & 1.0792 \\
\hline & $(-0.90)$ & $(-2.98)$ & $(-3.82)$ & $(-3.84)$ & $(-1.02)$ & (1.07) \\
\hline$N$ & 2136 & 2136 & 2136 & 2136 & 2136 & 2136 \\
\hline $\operatorname{adj} . R^{2}$ & 0.1579 & 0.0742 & 0.1812 & 0.0614 & 0.0115 & 0.0299 \\
\hline
\end{tabular}

Note: We observe the moderating effect of institutional ownership in the context of CSR-FP relationship. For this purpose, we estimate fixed effect model as a panel data analysis technique for entire profitability measures as a dependent variables and investment in corporate social responsibility (ICSR), institutional ownership (IO), and an interaction variable of ICSR and I0 (ICSR*IO) used as an independent variables; while firm size (Fsize), leverage (LVRG), firm age (Fage), and log of sales revenue (LSR) used as a control variables. Sample period is from 2010-2017 and finally composed 
of 268 non-financial PSX listed firms.

Moderating effect of IO in CSR-firm performance relationship presented in Table 5. The interactive variable of CSR and IO shows positive but insignificant relationship with firm performance in all measures. Although the results are insignificant but positive sign support the conflict resolution hypothesis that increases in CSR-expenditures having majority institutional holding firms resolve the issues among stakeholders and hence positively linked with firm's profitability by way of mitigating agency cost and overinvestment behavior of the management. Results support the findings of (Gillan et al., 2003; Starks, 2009) who corroborate positive impact of IO in CSR-firm value relationship.

\section{Summary and Conclusions}

This study examines the role of expenditures of CSR on FP by observing the moderating role of IO on a sample of 268 Pakistan stock exchange listed firms for the period 2010-2017. CSR is measured through the expenditure made by the organization in donations, charity etc. Firm's profitability is captured through ROA, ROE, Tobin's Q, NPM, ROS, and EY. Panel data techniques are employed concludes the findings of the study. The prime focus of the study is to observe the role of IO in the context of CSR-FP relationship. Particularly present study seeking whether the presence of IO mitigates agency conflict and overinvestment behavior of the management or it subdue this positive relationship by raising agency conflict and information asymmetry between shareholders and stakeholders?

The interaction between CSR-FP measures in first equation reveals that CSR has not impact on profitability in all measures except Tobin's Q. CSR concept is not longevous in Pakistan and still a large chunk of firms are ignoring this area deliberately. This could be the reason that in Pakistan, CSR is in a state of deprivation because stakeholders do not pay heed to this issue. Hence this does not affect the profitability of the firm. These results are in line with the findings of McWilliams and Siegel (2001), Lin et al., (2009), Singh (2014). Further, IO shows insignificant association towards firm profitability except Tobin's Q that has significant negative relationship. This negative association witnesses the agency issue and the strategic alliance hypotheses between large shareholders and the management at the expense of minority shareholders which ultimately destroy firm value. Moderating role of IO shows positive but insignificant association with firm's profitability. This positive association supports the conflict resolution hypothesis that IO through effective monitoring mitigating overinvestment and agency problems; hence positively associate between CSR-firm value relationship. Leverage, firm age, firm size and sales revenue show significant association with profitability in both equations. The outcome of this study shows concrete findings for top level managers, policy makers, supervisors, investors and future researchers in restructuring the governance mechanism that suit best in the context of Pakistan. There is a need to promote the CSR culture in Pakistan and create awareness regarding its role towards the betterment of community in general and society as a whole. This will not only increase its adaptability but linked positively with profitability as well. Future research may be carried out in the perspective of family ownership and foreign ownership alike and discuss their effect in the connection between CSR-profitability relationships.

\section{References}

Afza, T., \& Slahudin, C. (2007). Role of Institutional Investors and Firm Performance in an Emerging Market. Paper presented at the Singapore Economic Review Conference (SERC) 2007 held on 01-04 August, 2007, Singapore.

Al-Malkawi, \& Pilai, R. (2018). On the relationship between corporate governance and firm performance: Evidence from GCC countries. Research in international business and Finance 44, 394-410

Alipour, M., \& Amjadi, H. (2011). The Effect of Ownership Structure on Corporate Performance of Listed Companies in Tehran Stock Exchange: An Empirical Evidence of Iran. International Journal of Business and Social Science, 2(13),49-55.

Anderson, D.R., Sweeney, D.J. and Williams, T.A. (1990), Statistics for Business and Economics, South Western College, Cincinnati, OH.

Arnold, D.G. and Valentin, A. (2013) 'Corporate social responsibility at the base of the pyramid', Journal of Business Research, Vol. 66, No. 10, pp.1904-1914.

Baltagi, B. H., Bratberg, E., \& Holmås, T. H. (2005). A panel data study of physicians' labor supply: The case of Norway. Health Economics, 14 (10), 1035-1045.

Barnea, A. and A. Rubin (2010). Corporate Social Responsibility as a Conflict Between Shareholders. Journal of Business Ethics 97, 71-86.

Barnett, M.L. (2007), "Stakeholder influence capacity and the variability of financial returns to corporate social responsibility", Academy of Management Review, Vol. 32 No. 3, pp. 794-816. 
Bernadette, M. R., Muralidhar, K., Brown, R. M., Janney, J. J., \& Paul, K. (2001). An empirical investigation of the relationship between change in corporate social performance and financial performance: A stakeholder theory perspective. Journal of Business Ethics, 32(2), 143-156.

Bowen, H.: (1953), 'Social Responsibilities of the Business- Man' (Harper \& Row, New York).

Brammer, S., Brooks, C., Pavelin, S., 2006. Corporate social performance and stock returns: UK evidence from disaggregate measures. Financ. Manag. 35 (3), 97-116.

Brown, T. J., \& Dacin, A. (1997). The company and the product: Corporate associations and consumer product responses. Journal of Marketing, 61, 68-84.

Burkart, M., Gromb, D., Panunzi, F., 1997. Large shareholders, monitoring, and the value of the firm. Q. J. Econ. 112 (3), 693-728.

Carroll, A. B. (1991). The pyramid of corporate social responsibility: Toward the moral management of organizational stakeholders. Business Horizons, 34(4), 39-48.

Cespa, G., Cestone, G., 2007. Corporate social responsibility and managerial entrenchment. J. Econ. Manag. Strateg. $16(3), 741-771$.

Chapple, W., \& Moon, J. (2005). Corporate Social Responsibility (CSR) in Asia A Seven-Country Study of CSR Web Site Reporting. Business \& Society, 44(4), 415-441.

Chen, X., Harford, J., Li, K., 2007. Monitoring: which institutions matter? J. Financ. Econ. 86 (2), $279-305$.

Clarkson, M. E. (1995). A stakeholder framework for analyzing and evaluating corporate social performance. Academy of Management Review, 20(1), 92-117.

Cornell, B. and Shapiro, A.C. (1987), "Corporate stakeholders and corporate finance”, Financial Management, Vol. 16 No. 1, pp. 5-14.

Carroll, A. B., \& Shabana, K. M. (2010). The business case for corporate social responsibility: A review of concepts, research and practice. International journal of management reviews, 12(1), 85-105.

Craswell, A. T., Taylor, S. L., \& Saywell, R. A. (1997). Ownership structure and corporate performance: Australian evidence. Pacific-Basin Finance Journal, 5(3), 301-323.

Crisóstomo, V., de Souza Freire, F., Cortes de Vasconcellos, F., 2011. Corporate social responsibility, firm value and financial performance in Brazil. Soc. Responsib. J. 7 (2), 295-309.

Cui, J., Jo, H., Na, H., 2018. Does corporate social responsibility affect information asymmetry? J. Bus. Ethics 148 (3), 549-572.

Donaldson, T., \& Preston, L. E. (1995). The stakeholder theory of the corporation: Concepts, evidence, and implications. Academy of Management Review, 20(1), 65-91.

Donham, W.: 1927, 'The Social Significance of Business', Harvard Business Review 4, 406-419.

Edmans, A., 2014. Blockholders and corporate governance. Annu. Rev. Financ. Econ. 6 (1), $23-50$.

Fisman, R., G. Heal and V. Nair (2005). Corporate Social Responsibility: Doing Well by Doing Good?. Working paper, Wharton School, University of Pennsylvania.

Freeman, R., 1984. Strategic Management: A Stakeholder Approach. Massachusetts Pitman Publishing.

Freedman,M. and Jaggi, B. (1988), "An analysis of the association between pollution disclosure and economic performance", Accounting, Auditing \& Accountability Journal,Vol.1No. 2, pp.43-58.

Galbreath, J., \& Shum, P. (2012). Do customer satisfaction and reputation mediate the CSR-FP Link? Evidence from Australia. Australian Journal of Management, 37(2), 211-229.

Gillan, S.L., Starks, L.T., 2003. Corporate governance, corporate ownership, and the role of institutional investors: a global perspective. J. Appl. Finance 13, 4-22.

Gillan, S., Hartzell, J., Koch, A., Starks, L. (2010) Firms environmental, social and governance (ESG) choices, performance, and managerial motivation. Unpublished working paper, Texas Tech University and University of Texas at Austin.

Goss, A. and G. Roberts (2007). Corporate Social Responsibility and the Cost of Debt Financing. Working paper, York University.

Guenster, N., Bauer, R., Derwall, J., Koedijk, K., 2010. The economic value of corporate ecoefficiency. Eur. Financ. Manag. 17, 679-704.

Guiso, L., P. Sapienza and L. Zingales (2004). The Role of Social Capital in Financial Development'. American Economic Review 94, 526-556.

Guiso, Luigo, Sapienza, Paola, Zingales, L., (2015). The value of corporate culture. J. Financ. Econ. 117, 60-76. 
Harjoto, M.A., Jo, H., 2015. Legal vs. normative CSR: differential impact on analyst dispersion, stock return volatility, cost of capital, and firm value. J. Bus. Ethics 128 (1), 1-20.

Hussain, W., \& Moriarty, J. (2016). Accountable to whom? Rethinking the role of corporations in political CSR. Journal of Business Ethics, 1-16.

Jamali, D. (2008a). A stakeholder approach to corporate social responsibility: A fresh perspective into theory and practice. Journal of Business Ethics, 82(1), 213-231.

Jensen, M. C., \& Meckling, W. H. (1976). Theory of the firm: Managerial behavior, agency costs and ownership structure. Journal of Financial Economics, 3(4), 305-360.

Jensen, M. C. (1993). The modern industrial revolution, exit, and the failure of internal control systems. The Journal of Finance, 48(3), 831-880.

Jensen, M.: (2002). Value Maximization, Stakeholder Theory, and the Corporate Objective Function. Business Ethics Quarterly 12, 235-256.

Jiao, Y., 2010. Stakeholder welfare and firm value. J. Bank. Financ. 34, 2549-2561.

Jo, H., Harjoto, M.A., 2011. Corporate governance and firm value: the impact of corporate social responsibility. J. Bus. Ethics 103 (3), 351-383.

Jo, H., Harjoto, M.A., 2012. The causal effect of corporate governance on corporate social responsibility. J. Bus. Ethics 106 (1), 53-72.

Johnson, G., \& Scholes, K. (2002). Exploring corporate strategy: Text and cases (6th ed.). London: Financial Times Prentice Hall.

Jones, T. (1995), "Instrument stakeholder theory: a snapper of ethics and economics", Academy of Management Review, Vol. 2, pp. 404-37.

Kamel, H. and Shahwan, T. (2014), "The association between disclosure level and cost of capital in an emerging market: evidence from Egypt", Afro-Asian Journal of Finance and Accounting, Vol. 4 No. 3, pp. 203-225.

Knack, S. and P. Keefer: 1997, 'Does Social Capital have an Economic Payoff? A Cross-Country Investigation', Quarterly Journal of Economics 112, 295-321.

Karaosmanoglu, E., Altinigne, N., \& Isiksal, D. G. (2016). CSR motivation and customer extra-role behavior: Moderation of ethical corporate identity. Journal of Business Research.

Krüger, P., 2015. Corporate goodness and shareholder wealth. J. Financ. Econ. 115 (2), 304-329.

La Porta, R., F. Lopez-de-Silanes, A. Shleifer and R. Vishny (1997a). Legal Determinants of External Finance. Journal of Finance 52, 1131-1150.

Laan, G.V., Ees, H.V. and Witteloostuijn, A.V. (2008), "Corporate social and financial performance: an extended stakeholder theory, and empirical test with accounting measures”, Journal of Business Ethics, Vol. 79, pp. 299310.

Lemmon, M., Lins, K., 2003. Ownership structure, corporate governance, and firm value: evidence from the East Asian financial crisis. J. Financ. 58, 1445-1468.

Leventis, S. and Weetman, P. (2004), "Voluntary disclosures in an emerging capital market: someevidence from the Athens stock exchange", Advances in International Accounting, Vol. 17 No. 1, pp. 227-250.

Lin, C-H., Yang, H-L. and Liou, D-Y. (2009) 'The impact of corporate social responsibility on financial performance: evidence from business in Taiwan', Technology in Society, Vol. 31, No. 1, pp.56-63.

Makni, R., Francoeur, C., Bellavance, F., 2009. Causality between corporate social performance and financial performance: evidence from Canadian firms. J. Bus. Ethics 89 (3), 409.

McConnell, J. J., \& Servaes, H. (1990). Additional evidence on equity ownership and corporate value. Journal of Financial Economics, 27(2), 595-612.

McWilliams, A. and Siegel, D. (2001), "Corporate social responsibility: a theory of the firm perspective", Academy of Management Review, Vol. 26 No. 1, pp. 117-27.

Mian, S. N. (2010). Corporate social disclosure in Pakistan: A case study of fertilizers industry. The Journal of Commerce, 2(1), 1.

Mitra, S., 2002. The Impact of Institutional Stock Ownership on a Firm's Earnings Management Practice: An Empirical Investigation. Louisiana State University.

Mahoney, L. and Roberts, R.W. (2007), "Corporate social performance, financial performanceand IO in Canadian firms", Accounting Forum, Vol. 31 No. 3, pp. 233-53.

Moore, G. (2001), "Corporate social and financial performance: an investigation in the UK supermarket industry", 
Journal of Business Ethics, Vol. 34 Nos 3/4, pp. 299-316.

Navissi, F., \& Naiker, V. (2006). IO and corporate value. Managerial Finance, 32(3), 247-256.

Nelling, E., Webb, E., 2009. Corporate social responsibility and financial performance: the "virtuous circle" revisited. Rev. Quant. Finan. Acc. 32, 197-209.

Omar, B. and Simon, J. (2011), "Corporate aggregate disclosure practices in Jordan", Advances in Accounting, Incorporating Advances in International Accounting, Vol. 27 No. 1, pp. 166-186.

Patten, D.M. (1990), "The market reaction to social responsibility disclosures: the case of the Sullivan principles signings", Accounting, Organization and Society, Vol. 15, pp. 575-87.

Pirsch, J., Gupta, S. and Grau, S.L. (2006) 'A framework for understanding corporate social responsibility programs as a continuum: an exploratory study', Journal of Business Ethics, Vol. 70, No. 2, pp.125-140.

Pound, J. (1988). Proxy contests and the efficiency of shareholder oversight. Journal of financial economics, 20(1), 237265.

Roberts, R.W. (1992), "Determinants of corporate social responsibility disclosure: an application of stakeholder theory", Accounting, Organisations and Society, Vol. 17 No. 6, pp. 595-612.

Salmones, M. G., Perez, A., \& Bosque, I. R. (2009). The social role of financial companies as a determinant of consumer behaviour. International Journal of Bank Marketing, 27(6), 467-485

Salzmann, O., Somers, A. and Steger, U. (2005), "The business case for corporate sustainability: literature review and research options", European Management Journal, Vol. 23 No. 1, pp. 27-36.

Scherer, A.G.; Palazzo, G.; Baumann, D. (2006) Global rules and private actors: Toward a new role of the transnational corporation in global governance. Bus. Ethics Q. 16, 505-532.

Shahab, Y., Ntim, C.G., Chengang, Y., Ullah, F., \& Fosu, S. (2018). Environmental policy, environmental performance, and financial distress in China: Do top management team characteristics matter? Business Strategy and the Environment, 27: 1635-1652.

Shleifer, A. and R. Vishny: 1986, 'Large Shareholders and Corporate Control', Journal of Political Economy 94, 461488.

Simpson,W.G. andKohers, T. (2002), "The link between corporate social and financial performance: evidence from the banking industry", Journal of Business Ethics, Vol. 35, pp. 97-109.

Singh, S. (2014) Impact of Corporate Social Responsibility Disclosure on the Financial Performance of Firms in UK, Master of Business Administration-Financial Management, University of Twente [online] http://essay.utwente.nl/65014/(65014) (accessed 20 July 2016).

Snider, J., Hill, R.P. and Martin, D. (2003), “Corporate social responsibility in the 21 st century: a view from the world's most successful firms", Journal of Business Ethics, Vol. 48 No. 2, pp. 175-87.

Starks, L., 2009. Corporate governance and corporate social responsibility: what do investors care about? What should investors care about? Financ. Rev. 44, 461-468.

Steger, U., Somers, A. and Salzmann, O. (2007), "The economic foundations of corporate sustainability", Corporate Governance, Vol. 7 No. 2, pp. 162-77.

Stuebs, M. and Sun, L. (2015), "Corporate governance and social responsibility", International Journal of Law and Management, Vol. 57 No. 1, pp. 38-52.

United Nations (2010), "Overview of the UN global compact", available at: www.unglobalcompact. org /AboutTheGC/index.html (accessed 10 February 2016).

Vance, S.C. (1975), “Are socially responsible corporations good investment risk?”, Management Review, Vol. 64 No. 8 , pp. $18-24$.

Verdeyen, V., Put, J., \& Van Buggenhout, B. (2004). A social stakeholder model. International Journal of Society Welfare, 13, 325-331.

Visser, W. (2010). CSR 2.0: The evolution and revolution of corporate social responsibility. Responsible business: How to manage a CSR strategy successfully, 311-328.

Waddock, S.A. and Graves, S.B. (1997), "The corporate social performance-financial performance link", Strategic Management Journal, Vol. 18, pp. 303-19.

Walsh, Gianfranco, \& Beatty, Sharon (2007). Customer-based corporate reputation of a service firm: Scale development and validation. Journal of the Academy of Marketing Science, 35(1), 127-143.

Wood, D. J., \& Jones, R. E. (1995). Stakeholder mismatching: A theoretical problem in empirical research on corporate social performance. The International Journal of Organizational Analysis, 3(3), 229-267. 
Yoon, Y., Giirhan-Canli, Z. and Schwarz, N. (2006), "The effect of corporate social responsibility (CSR) activities on companies with bad reputations", Journal of Consumer Psychology,Vol. 16 No. 4, pp. 377-90.

Yunis, M., Jamali, D., \& Hashim, H. (2018). Corporate Social Responsibility of Foreign Multinationals in a Developing Country Context: Insights from Pakistan. Sustainability, 10(10), 3511. 